\title{
Introduction: Is it Possible to Produce Gender/Sexual Justice in Greater China and Singapore?
}

\author{
Man-Chung Chiu
}

Published online: 7 April 2012

(C) Springer Science+Business Media B.V. 2012

\begin{abstract}
In the article, the author argues that since injustice still exists in the milieu of Gender and Sexuality of Greater China and Singapore; legal reform has to be introduced. In the age of Globalization, related legal reform can be carried out by transplanting related law from other jurisdictions, but cautions should be applied in handling the dynamics/dialogue between indigenous traditions and modernities. The article also discusses how religion can be facilitated as a platform where transplantation can happen smoothly.
\end{abstract}

Keywords Justice · Gender - Sexuality · Globalization · Transplantation · Religion

This volume seeks to engage the discourses and matrices of law in Greater China (including mainland China, Taiwan, Macau and Hong Kong) ${ }^{1}$ and Singapore with gender/sexual politics. The key question that underlines all articles in this volume is: Can we produce gender/sexual justice in Greater China and Singapore?

Law in Greater China and Singapore are always used as the machines to produce/ defend rights, including the sexual rights; and it seems substantial improvement in related law has been made in the last few decades: ${ }^{2}$ Women's Charter in Singapore was passed in 1961, and in 2007, Prime Minister Hsien-loong Lee decided that oral and anal sex conducted between opposite sex would be decriminalized; ${ }^{3}$

\footnotetext{
1 Please note that: Macao is also considered as part of Greater China. For details, please see Harding (1993).

${ }^{2} \mathrm{Gu}$ (2010: 8); Zhou (2009: 212).

3 Leong (2010: 586).
}

MC Chiu $(\bowtie)$

Department of Law and Business, Hong Kong Shue Yan University, 10 Wai Tsui Crescent, Braemar Hill Road, North Point, Hong Kong e-mail: mcchiu@hksyu.edu 
in mainland China, the criminal offence of hooliganism, which was used to arrest and prosecute males practicing anal sex, was repealed in 1997; in Taiwan, Gender Equality Education Act and Children and Youth Welfare Law was enacted in 2004 and 2010 respectively; and in Hong Kong, in Leung William v. Secretary for Justice $^{4}$ the law prohibiting anal sex, was held unconstitutional in 2006, and same sex couples have been under the protection of Domestic and Cohabitation Relationships Violence Ordinance ${ }^{5}$ since 2010.

However, we can still see law malfunctions and fails to respect differences and deny equality very often in this part of the world: In mainland China, besides the fact that there is an absence of legislation controlling domestic violence, Zhang, in 'Progresses, Challenges and Suggestions on Legislative Efforts of Combating Sexual Violence against Children in Mainland China', contends and points out that there are still many loopholes of the current mainland Chinese legislations in controlling child sexual abuse. Lesbians, gays and transgenders in Taiwan, who do not enjoy any legal protection, are still banned from donating blood and joining the military police. ${ }^{6}$ In Hong Kong, transgenders/transsexuals/LBGs cannot get married. ${ }^{7}$ Further, as Leong points out in his article, oral sex that happen between same sex is still prohibited in Singapore. In Macao, a special administrative region in Mainland China, a law protecting the rights of lesbians, gays and transgenders and law controlling domestic violence (See Hsieh in this volume) is still absent.

\section{Gender/Sexual Justice and Globalization}

If we are going to introduce legal reform so as to produce a legal discourse/machine capable of upholding justice, it is inevitable that a framework should be set up to examine the societal cultures and subjects in the age of globalization. In 'The SocioCultural Exclusion and The Regulation of Sexuality in Taiwan', Ning notes that while globalization has undermined 'the cohesive power' of the society, the recent change of the culture and legal regulations have signaled significant transformations in the interaction between Taiwanese civil society and its nation-state. He argues that as a consequence of the development of the exclusive society and the new regulatory state, a 'culture war' between socio-cultural exclusion and social freedom (especially in the area of sexuality) is now being waged in Taiwan's civil society. One of the outcomes is that it has become more difficult for the gays to get access to resources which are available to the straights; also, their culture is less valued.

If on one hand, globalization means the production of a common world, ${ }^{8}$ a single capitalism with multiple expressions and articulations, ${ }^{9}$ and a world where nations

\footnotetext{
${ }^{4}$ CACV317/2005.

${ }^{5}$ Section 2(1), Cap 189 LHK.

${ }^{6}$ Xie (2004: 375-376).

${ }^{7}$ W v. Registrar of Marriages HCAL 120/2009.

${ }^{8}$ Hardt and Negri (2009: viii).

${ }^{9}$ Dirlik (2003, 2007).
} 
are only longer the naturally vital, ${ }^{10}$ then on the other, according to Sun, it is not a hegemonization of a particular civilization, but a development and hybridization of cultures, globalization therefore is always a becoming and never denies the power differences between nations/cultures. ${ }^{11}$ Globalization also signifies the birth of a new order which is marked by the undermining of state power (see Ning's article), diasporic identities and fluid communities. ${ }^{12}$ Singapore perhaps is one of the best examples of this theoretical perspective: Leong's article points out that Singapore is mostly a diasporic society and '[d]iasporic communities tend to be obsessed with their roots'; however, 'they are highly selective in what they choose to be nostalgic about'.

The transplantation of international human rights law can best elaborate the dynamics of globalization and localization, and, as Hsieh writes in 'The Right to be free from Domestic Violence in Macau', the process itself can also illustrate how legal development can go beyond such a dichotomy.

In the age of globalization, where there exist multiple modernities or hybridization of global modernities, Asia is 'cleaver even more strongly to its tradition'. ${ }^{13}$ Local culture, especially tradition, is usually considered as the source of resistance against globalization. ${ }^{14}$ Then, would cultural tradition produce justice?

Take Han Chinese traditional culture, which is one of the three dominant elements in forming the Asian culture (see Leong in this volume; the rest are Japanese culture and Indian culture), as an example: Han Chinese law was patronizing and patriarchal (See Hsieh in this volume). According to Qing Code, senior members of a family (for example, grandparents and parents) can assault, or even kill, junior members (like grandchildren and daughters, sons), in name of teaching, and it was never considered a crime. In other words, issue of equality was totally ignored in the machine of domestic violence. And, women never had any right to divorce before 1911, when the Republic of China was established. ${ }^{15}$ Even though nowadays, laws related to gender equality and protection for the powerless (for example, abused children) are enacted in most of the jurisdictions influenced by Han-Chinese traditional culture (except for Macau), ${ }^{16}$ discriminatory traditions (like misogynist attitude in relation to one child policy which causes low survival of female babies in rural areas of mainland China ${ }^{17}$ and the 'small house policy' which can only be enjoyed by the male indigenous residents in New Territories, Hong Kong ${ }^{18}$ ) still exist and energize/format the gender/sexuality machine/discourse. ${ }^{19}$

\footnotetext{
${ }^{10}$ Loomba, Kaul, Bunzl and Burton (eds) (2005: 22, 63).

11 Sun (ed) (2011: 19).

12 Loomba, Kaul, Bunzl and Burton (eds) (2005: 22, 65).

13 Lo (2010: 13).

14 Loomba, Kaul, Bunzl and Burton (eds) (2005: 19, 207).

15 He and Chen (2009: 12-25).

16 Vong (unknown)

17 Li (2009: 178, 191).

18 Chiu (2011a b), Chiu (2006).

$19 \mathrm{Li}$ (2009). There was a debate in relation to whether tradition still has a role in contemporary society, in the article 'Simularizing Tradition and Foreign: Osmotic Production of Justice in the Milieu of Hong Kong Anti-Domestic Violence Law', I argue, from a Deleuzean perspective, that when present always
} 
While I am arguing that tradition is still influential nowadays, an authentic notion of tradition does not exist-as Deleuze points out: past is only a virtuality; so, 'tradition' is also contested in its own terms, ${ }^{20}$ as people can have different and multiple understandings and interpretations of tradition/past. That is why there was once a law against male same sex activities in mainland China and in Hong Kong in the 20th Century; although there is evidence showing the otherwise, people nowadays still argue that Han Chinese are homophobic. ${ }^{21}$ Tradition becomes part of the social control force which allows changes when tradition actualizes. In other words, tradition and modernities do not always 'constitute two clearly distinguishable moments'. ${ }^{22}$ That explains why, when Chiu, in 'Confession of Law? A critical perspective on production of child subject in Hong Kong law controlling child sexual abuse', argues that deageization can be a legal reform strategy, he refers to the moments and instances in Han Chinese history where age was not an element constituting and producing a subject, and argues that those moments can be the platform for the transplantation of strategy and related concepts.

Tradition cannot be static as the subject can change the discourse/machine (including tradition and legal institutions) where it is produced, i.e. there is an interactive constitution between subjectivity and discourse/machine. ${ }^{23}$ So, while Povinelli writes that the meaning of subjectivity depends on the social context, ${ }^{24}$ it is not a one way traffic; social context is also reproduced by (the activities of) subjects. In other words, it also provides the possibilities and spaces for social change, initiated by individual subjects. While the process of interactive constitution never ends, discourse/machine and subjects are always becoming. ${ }^{25}$

If the subject is always becoming and discursive, then is it possible to use age and gender to fixate a person's identity? This is the question raised by the author of 'Confession of Law'. While people always claim that children need legal protection as they are weak and powerless (see Leong, Ning and Zhang of this volume), Chiu argues that with the impossible territorialization, conducted (partly) by law machine, there is no essential and natural connection between age and formation of subject; the binary of child and adult can be very meaningless in the context of legal regulation of human sexual activities.

\footnotetext{
Footnote 19 continued

falls into the past, past also actualizes and becomes part of the present, so history and tradition are always part of the contemporary social control. For details, please see Chiu (2011a, b).

${ }^{20}$ Loomba, Kaul, Bunzl and Burton (eds) (2005: 19, 211).

21 Zhou (2009: 48, 49). Please note that, only since Qing Dynasty (1644-1911), law started to illegalize male-and-male sexual activities.

22 Loomba, Kaul, Bunzl and Burton (eds) (2005: 19, 211).

23 Kam (2002: 6).

24 Loomba, Kaul, Bunzl and Burton (eds) (2005: 153).

25 Hardt and Negri (2009: 112).
} 


\section{Go Beyond a Binary Paradigm}

Comparative research is a very common approach investigating issues of regional interest. A comparative study can be very productive: when comparing the machines and discourses of different cultures, countries and jurisdictions, for example, we know that protection of rights are not universal and are not all rounded in mainland China. ${ }^{26}$ We can also learn from other cultures and jurisdictions how comprehensive respect and defense of sex rights can be achieved and created (by law).

Engaging perspectives of comparative studies with re-production of gender/sexual justice, scholars and activists in parts of Asia advocate not only the subversion of heterosexist patriarchal structure but also the challenge of imperialism. ${ }^{27}$ Although postcolonial studies can sensitize comparative gender/sexuality research and politics towards the power difference between cultures, a (orientalist) binary of, or a scale with (masculinized) Western civilization and (femininized) Eastern/Chinese culture on both ends, is always reproduced. ${ }^{28}$ Comparative studies thus always easily fall into a dichotomous examination, for example: when investigating masculinities, analysis like 'In contrast to Western "real men" who always get the girl, the $w u$ hero must contain his sexual and romantic desire. ${ }^{29}$ This world view permeates the development of socio-legal policy suggestion and analysis: in order to create gender/sexual justice, Taiwan society should switch from a 'patriarchal' capitalist market economic structure to a 'matriarchal' social welfare system. ${ }^{30}$

The binary paradigms (feminine vs. masculine, Asian/Eastern vs. Western, Capitalism vs. Social Welfare, matriarchy vs. patriarchy, localization vs. globalization), however, easily neglect or ignore the differences and multiplicities: For instance, globalization and transplantation of overseas concept may instantaneously introduce both the socio-legal interdiction and acceptance of same sex erotic desire/ activities. ${ }^{31}$ This ignorance may lead to the fact that one of the perspectives will be adopted as a universal and exclusive standard: when comparing the Eastern philosophy, and Western philosophy, Sheng, the Chief Advisor to the China Banking Regulatory Commission, writes:

What eastern philosophers have failed to do in the modern world is explain using western science and technology terms what the values of 'man and nature are one' mean in daily practice. ${ }^{32}$

What Sheng means, in short, is: unless Eastern philosophy adopts Western philosophical language and jargon in elaborating and explaining their ideas, the

\footnotetext{
${ }^{26} \mathrm{Li}(2009: 1)$

${ }^{27} \mathrm{Gu}(2010: 8)$

${ }^{28}$ Said (1978). Fang (2008), when investigating the contemporary studies of Chinese masculinity, tries to go beyond this binarism and argues that contemporary Chinese masculinity has natures of both Western roughness and traditional Chinese gentleness. (43).

${ }^{29}$ Kam (2002: 19).

${ }^{30}$ Huang (2009: 49).

${ }^{31}$ Huang (2011).

${ }^{32}$ Sheng (2011).
} 
former is doomed to be a failure. It is the opposite in Singapore, where Asian Sexuality (an Eastern concept) is adopted as the legal standard there (see Leong in this volume). The key question is not which perspective should be used as the standard, but why should there be 'a' standard. Leong's article says that a standard is only a virtuality and how important particularities are and why singularities are significant in analysis: it is not only because each society is different, but also because individual desire and the past of each culture that activate the machine varies and is fluid, a binary paradigm cannot effectively and efficient carry exhaustively the changing differences. In his article, Leong challenges the concept of 'Asian sexuality' and questions the dichotomy of 'West versus the East (Asian)'. This subversion is vital, according to Leong, as the ideologies have been the rationale for the repressive sexual policies constructed by the Singaporean authorities. Leong also argues that the Singaporean state authority prefer Asian Culture to Asian contemporary, because, as I put in the above section, tradition is partly a product of the present, so 'it is easier to invert the past than present'. Then why would the Singaporean version of 'Asian (traditional) culture' is so restrictive? Leong seems to implicitly suggest that it is due to the ruling party's interpretation of Christianity. Besides Leong, Ning also notes the significant influence of Christian groups in formatting the state policy in Taiwan. ${ }^{33}$

\section{Religion and Law: Can Buddhism be a Platform of Theory/Law Transplantation?}

When discussing the influence of Christianity on the development of state policy and law, we cannot ignore the possible effect of Buddhism and Daoism (or Taoism). ${ }^{34}$ There are always doubts in relation to the interaction between Asian religions and Law_questions like 'do Buddhism and Daoism, like Christianity, have any effect on the development of law?' are always asked-this is not only a vacuum of this special issue, but also a topic which lacks in-depth investigation.

Chen makes it clear that Buddhism does not only influence the development of state law, but also affects folk law in Greater China. ${ }^{35}$ That is not surprising especially when we know that Buddhism puts a lot of emphasis on the obedience of rules and regulations. ${ }^{36}$ When discussing the effect brought by Daoism, Liu rightly points out that religions, including Buddhism, can be the major force which promotes social change and evolution; and the religions do so by permeating their respect of rules and regulations through social customs, and state law. ${ }^{37}$

The influence of Asian religions on law can be illustrated by Buddhism: in Tang Dynasty (618-907) and Qing Dynasty (1644-1911), there were particular laws

\footnotetext{
33 For the increasing influence of Christian Groups in Taiwanese sexual politics, please also consult Huang (2011).

34 I choose to discuss these two religions because they are very influential in Greater China and Singapore.

35 Chen (2009: 1)

36 Liang (2009: 165).

37 Liu (2009: 234).
} 
controlling Buddhist nuns and monks, like law against murder and sexual activities (for example: sex between nuns and monks). ${ }^{38}$ Buddhism also affects the development of law in Burma: it was stated that wife was the husband's servant, wife could be divorced if she always brought forth female children. ${ }^{39}$ It therefore seems that Buddhism and related laws are in fact very discriminatory. The most mysterious contradiction is-one of the key Buddhist principles is equality:

Within my Dhamma, the 4 clans-(1) priestly, (2) military and ruling, (3) farmers and traders, and (4) serfs...would all drop their original titles and are called "Shih" students of Buddha. 40

In response to this dilemma, Shih Chao Hwei argues that Buddhist rules and regulations are also discursive products, and they are neither fixed nor universal. ${ }^{41}$ According to the Buddhist perspective, the interactive formation of body and the world thus (re)produces karma, which literally means 'action' and indicates the mechanism by which what a human did and/or thought in one point of time would determine her/his future action and/or status. ${ }^{42}$ Karma is not a kind of destiny predetermination, but a mechanism of choice and responsibility. ${ }^{43}$ Although according to karma, the action a human has to take is pre-determined, the manner of the action can still be decided, though not fully and completely, by her/him. Karma exercises through the production and depletion of bija, which is not a static concept-it grows with the changes of context-the mechanism is called 'Perfume (薰習)'. Every decision and action of human subject will influence the ever-changing nature of bija. This line of argument leads to the development of an important Buddhist teaching: 'Non-Insistence' (諸法無我), which means nothing is essential, natural and monolithic; the teaching forms the foundation of Buddhist equality principle. So, it is not surprising that, according to the interpretation of Engel and Engel, Buddhist justice is equality. ${ }^{44}$

Discussion of Buddhism is thus vital in relation to the development of law in Greater China and Singapore, because it can be used as the platform to facilitate the transplantation of theories originated and developed overseas, including justice, concepts and legal reform to produce justice.

\footnotetext{
38 Wang (2001: 121, 122); Qiu and Chen (2009: 192, 193).

39 Chan-Toon (1894: 22, 44).

40 Taisho Tripitaka Editorial Committee (1985) Vol. 22.

41 Shih (2009a, b).

$42 \mathrm{Hu}$ (1999: 9).

43 With regard to the interaction between Karma and subject, Shih Hong Xue further elaborates: 'The initial fertilization of foetus, according to Buddhist teaching, starts at the moment when the parents intercourse, due to the force of Dharma, vijnana gets into the foetus, absorbs the sperm of father and blood of mother, and make the life grow everyday until the birth of baby. The above action of vijnana, which the scholars of vijnanamatra titled Karma of life, reproduces the subject of Karma. (trans., 胎生有 情的最初受胎, 依佛法所說是由於識, 即當父母結合時, 主體的心識, 由於業力的牽引, 於一刹那投入 母胎, 吸取父精母血, 使生命一天天地增長起來, 以至於成人。這一入胎識, 唯識家稱其爲是生命果 報識,爲去後來先的果報主體.)'(Shih Hong Xue 2009: 70).

44 Engel and Engel (2010: 124).
} 
The question is: if Buddhism can be the cultural matrix and machine for equality, justice and antidiscrimination law to grow, why do we have to transplant overseas cultural concepts and related law reform? As I have argued elsewhere, justice does not necessarily mean equality in every culture. In Han-Chinese culture, justice is always translated as (Confucian) $\mathrm{Yi}$, which means righteousness that works appropriately and properly in harmonious hierarchical interrelationship, where equality is not emphasized. And then even where there is a paradigm of equalitylike Buddhism, there may be no philosophical perspective to facilitate and produce resistance against the traditional discriminatory paradigm and related practices: in the discourse of harmony, where conflicts and resistance are devalued, how can Daoism and Confucianism - two very dominant cultural forces in Greater China and Singapore-develop an effective strategy of subversive resistance ${ }^{45}$ Under Buddhist discourse, changes and reforms are allowed and accepted, but again, where is the motivation and what are the policies? That explains why Hsieh refers to international human rights law as a standard of law development in Macao, and Chiu has to adopt Deleuzean deterritorialization as the philosophical framework of reform policy. That can also demonstrate that resisting a binary understanding of world does not mean resisting the understanding of other cultures or transplantation of theories and related legal reform which originates from foreign jurisdictions.

We also need a standard to evaluate if the transplanted legal reform is successful and bring about legal reforms, we have to ask if the discriminated would accept them, and if the reforms would be successful. I advocated elsewhere that Rawlsian notion of justice can be the standard because it does not only stress the importance of equality, ${ }^{46}$ (see also Ning's article in this volume) it also emphasizes that only when the least advantaged in the society accepts the inequality, different distribution of resources is allowed. ${ }^{47}$ In short, Rawlsian theory of justice respects individual freedom and differences among human in the discourse of democracy and individualism. $^{48}$ When adopting Rawlsian perspective when discussing the proposed deageization of law in Hong Kong, where elections are held (though to a limited degree) and rule of law is already part of the tradition, we have to ask if the current non-adults (the targets of protection provided by current law) would accept the possible change brought by the reform. But, since Rawlsian theory can only be fully utilized in the democratic political system, then can it be used in mainland China, where democratic election seems to have a very different meaning? If so, which notion of justice should we adopt as the evaluation standard? And in a society where rule of law does not have a long history, can justice be produced by law? While Cornell believes that law can be a site where justice is constructed, ${ }^{49}$ Derrida argues that justice always exists out of law as justice is always deferred. ${ }^{50}$ The interconnection and interaction between justice and law is also at the same time full

\footnotetext{
45 Xie (2004: 215).

46 Rawls (1971). See also Sandel (2009: 9, 142).

47 Chow (2010: 37).

48 Lin (2008: 8, 29).

49 Heberie and Pryor (eds) (2008: 234).

50 Zartaloudis (2011: 141).
} 
of questions: Is juridical justice something out of law? Can juridical justice (only) be achieved by law $?^{51}$ Is justice a repetitive product of contingency? These are the questions that are worth further discussions.

\section{References}

Chan-Toon, 1894. The principles of Buddhist law Rangoon. Burma: Myles Standish \& Co.

Chiu, Man-chung. 2006. Negotiating Han-Chinese legal culture-postcolonial gender political discourse on Hong Kong small house policy. King's College Law Journal 17: 45-70.

Chiu, Man-chung. 2011a. Simularizing tradition and foreign: Osmotic production of justice in the Milieu of Hong Kong anti-domestic violence law. In New knowledge in a new era of globalization, ed. Piotr Pachura. Vienna: InTech.

Dirlik, Arif. 2003. Global modernity? Modernty in an age of global Capitalism. European Journal of Social Theory 6(3): 275-292.

Dirlik, Arif. 2007. Global modernity: Modernity in the age of global capitalism. Boulder: Colorado.

Engel, David M., and Jaruwan S. Engel. 2010. Tort, custom, and karma: Globalization and legal consciousness in Thailand Stanford. California: Stanford University Press.

Harding, Harry. 1993. The concept of "Greater China": Themes, variations and reservations. The China Quarterly 136: 660-686.

Hardt, Michael, and Antonio Negri. 2009. Commonwealth Cambridge. Mass: The Belknap Press of Harvard University Press.

Heberie, Renée J., and Benjamin Pryor (eds.). 2008. Imagining law on Drucilla Cornell. USA: State University of New York Press.

Huang, Tao-ming Hans. 2011. Queers politics and sexual modernity in Taiwan. Hong Kong: Hong Kong University Press.

Kam, Louie. 2002. Theorising Chinese masculinity: Society and gender in China. Cambridge: Cambridge University Press.

Leong, Wai-teng Laurence. 2010. Sexual governance and the politics of sex in Singapore. In Management of success: Singapore revisited, ed. Terence Chong. Singapore: Institute of Southeast Asian Studies.

Lo, Kwai-cheung. 2010. Excess and masculinity in Asian cultural production. USA: State University of New York Press.

Loomba, Annia, Suvir Kaul, Matti Bunzl, and Anoinette Burton (eds.). 2005. Postcolonial studies and beyond. Durham: Duke University Press.

Rawls, John. 1971. A theory of justice. Cambridge, MA: Harvard University Press.

Said, Edward. 1978. Orientalism. London: Routledege \& Kegan Paul.

Sandel, Michael. 2009. Justice: What's the right thing to do? New York: Farrar, Straus and Giroux.

Sheng, Andrew. 2011. River west, river west. Caixin Weekly: China Economics and Finance 39: 57-60.

Teubner, Gunther. 1998. Legal irritants, good faith in British law or how unifying law ends UP in new divergences. Modern Law Review 61(1): 11-32.

Vong, Hin-fai. 'Protection of Women's Rights and Interests in Macau' China Human Rights. http:// www.chinahumanrights.org/Messages/Focus/59/6/t20111008_801710.htm (last accessed 12 Nov 2011).

Zartaloudis, Thanos. 2011. On justice. Law and Critique 22: 135-153.

\section{Chinese References}

Chen, Den-wu (陳登武). 2009. Inferno, law, order in human world (trans., 地獄·法律·人間秩序) Taipei: WuNan Culture Enterprise (五南圖書).

Chen Ming-xia (陳明俠) and Huang, Lie(黄列) (eds). 2009. A reader of studies of gender and law (trans., 性別與法律硎究概論) Beijing: China Social Sciences Press (中國社會科學出版社).

\footnotetext{
51 Teubner (1998).
} 
Chiu, Man-chung (趙文宗). 2011b. 'It is both her/him and you/me' (「是她/他也是妳和我」:由W訴婚 姻登記處一案看香港跨性別法律機器) 83 Taiwan: A Radical Quarterly in Social Studies (台灣社 會研究雜誌) 329-354.

Chow, Po-chung (周保松). 2010. Politics of liberal equality (自由人的平等政治) Beijing: Joint Publishing Company.

Chu, Wei-cheng (朱偉誠) (ed). 2008 Critical sexual politics (批刵的性政治) Taipei: TaiShe (臺灣社會 㗑究雜誌社).

Fang, Gang (方剛). 2008. The study on Masculinities and men's movement (男性㸴究與男性運動) JiNan: ShangDong People Publishing House.

Gu, Xiu-lian (顧秀蓮). 2010. Women's development with Chinese characteristics (trans., 中國持色婦女 發展之路) Beijing: People's Publishing House.

He Qin-hua (何勤華) and Chen Ling-hai (陳靈海). 2009. Law, society and thought: An investigation to the background of Chinese traditional legal culture (法律、社會與思想: 對傳统法律文化背景的 考察) Beijing: Law Press.

$\mathrm{Hu}$, Xiao-guang (胡曉光). 1999. 'Alaya-Vijnana: an opinion (trans. 阿賴耶識媰議)' 4 FaYin (法音) 9. Huang Hans tao-ming. (黄道明). 2009. 'Modernising gender, Civilising sex (良家婦女的性變態想像)' 75 Taiwan: A Radical Quarterly in Social Studies (台灣社會硎究雜誌) 45-84.

Ji, Jin-qing (紀金慶) 2008. Conflict and harmonization of Binarism and Yin-Yang world view (trans., 二 元對立與陰陽世界觀的衝突與調和) Taipei: 台灣商務.

Li Yin-he (李銀河). 2009. Women in the back village: Gender power relations in rural areas (後村的女人 們：農村性別權力關係) Hohhot: Inner Mongolia University Press.

Li，Yong-jun (李擁軍). 2009. Sexual rights and law (性權利與法律) Beijing: Science Press (科學出版社).

Liang, Zhi-ping (梁治平). 2009. Thinking at the margin (在邊緣外思考) Beijing: Law Press.

Lin Huo-wang (林火旷) 2008. Justice and Citizenship (正義與公民) ChangChun: .JiLin Publishing Group.

Liu, Shao-yun (劉紹雲). 2009. Religious rule and social order (trans., 宗教律法與社會秩序) ChangDu: Ba Shu shu she(巴蜀書社).

Ma, Xiao-hong (馬小紅). 2009. Perspective on law in ancient Chinese society (trans., 中國古代社會的 法律觀) Zhengzhou: DaXiang.

Qiu, Peng-sheng(邱澎生) and Chen, Xiyuan(陳 遠). 2009. Power and culture of legal mechanism in Ming and Qing (trans., 明清法律運作中的權力與文化) Taipei: Academia Sinica and Linking Books(聯 經出版).

Shih Chao-hwei (釋昭慧). 2009a. Preliminary systematic theorization of Buddhist ethics (佛教後設倫理 學) Taipei: Dharma-Dhatu Publications(法界出版社).

Shih Chao-hwei (釋昭慧). 2009b. In-depth investigation of Fa and Lu (trans 法與律之深層探索論集) Taipei: Dharma-Dhatu Publications (法界出版社).

Shih Hong-xue (釋弘學). 2009. Introduction to Vijnanamatra(trans., 唯識學概論) ChangDu: Ba Shu shu she(巴蜀書社).

Sun, Hong-bin (孫洪斌) (ed) (2011) Cultural Globalization (trans., Wen hua quan qiu hua yan jiu, 文化全 球化硎究) ChengDu: SiChuan University Press.

Taisho Tripitaka Editorial Committee (trans. 大藏經刊行委員會). 1985. Vijnaptimatratasiddhi-sastra, Taisho Tripitaka (大正新修大藏經) Taipei: XinWenFeng (新文豐).

Wang, Li-min (王立民). 2001. Legal theory and legal system (trans., 法律思想與法律制度) Beijing: China University of Political Science and Law Press 中國政法大學出版社.

Xie Hua (謝暉). 2003. The concept and foundation of faith in law (trans., 法律信仰的理念與基礎) JiNan: ShangDong People Publishing House.

Xie Wo-long (謝臥龍) (ed). 2004. Representation and performance of TongZhi in state of rainbow (trans., 霓虹國度中同志的隱現與操演) Taipei: TongShan Publication Inc (唐山出版社).

Yang, Hui-nan (楊惠南). 2005. Compassion and belief (愛與信仰) Taipei: Business Weekly Publication (商周出版).

Zhang, Shi-ming (張世明), Bu De-mao (步德茂) and Na He-ya (娜鶴雅) (eds). 2010 Recent international scholarship on traditional Chinese law (世界學者論中國傳統法律文化1644-1911) Beijing: Law Press.

Zhou, Dan (周丹). 2009. Pleasure and discipline; jurisprudential imagination of same-sex desire in chinese modernity (愛悅與規訓:中國現代性中同性慾望的法理現象) GuiLin: GuangXi Normal University Press. 